\title{
Media Baru dan Perubahan Sosial (Kasus Intervensi TIK di pesisir Desa Drajat Kabupaten Lamongan)
}

\author{
New Media and Social Change \\ (Case of ICT Intervention in Coastal Village of Drajat Lamongan \\ Regency)
}

\section{Djoko Waluyo ${ }^{1}$ \\ Yevi Herviyanti ${ }^{2}$}

${ }^{1}$ Peneliti Ahli Utama Puslitbang Aptika- IKP,Badan Litbang SDM

${ }^{2}$ Penyuluh Sosial Pertama Balai Rehabilitasi Sosial Penyandang Disabilitas

Sensorik Netra Tan Miyat

${ }^{1}$ Kementerian Komunikasi dan Informatika. Jalan Medan Merdeka Barat No.9, Jakarta 10110

${ }^{2}$ Kementerian Sosial, Bekasi. Jalan HM Joyomartono Nomor 19, Bekasi Timur 11jok016@kominfo.go.id ;2 yevi.herviyanti@kemsos.go.id

Dikirim: 29 November 2021, Direvisi: 27 Desember 2021, Diterima: 27

Desember 2021, Terbit: 31 Desember 2021. Sitasi: Waluyo, Herviyanti.

(2021). Media Baru dan Perubahan Sosial (Kasus Intervensi Tik di Pesisir

Desa Drajat Kabupaten Lamongan), PRoMEDIA. Volume 7 (2), Desember

2021, hal 375- hal 412.

\begin{abstract}
The presence of new media in the form of the internet that can be accessed by the public will be a factor that will influence the occurrence of social change in the community. Drajat village, which is located on the north coast of the eastern part of the island of Java, which was originally a poor community, is increasingly able to increase its income to market seafood and other food via the internet. Traditional life is increasingly changing with urban characteristics. BUMDes can make a big contribution to encouraging economic change for the Drajat village community. This article approaches qualitatively with a qualitative-descriptive analysis method. Data collection techniques with in-depth interviews with village head informants, Karang Taruna leaders,
\end{abstract}


BUMDes administrators, ICT activists and fishermen, as well as farmers. internet intervention.

Keywords: Internet, social change, coastal areas

\begin{abstract}
ABSTRAKSI
Kehadiran media baru berupa internet yang dapat diakses oleh masyarakat, akan dapat menjadi factor yang mempengaruhi bakal terjadinya suatu perubahan social pada masyarakat tersebut. Desa Drajat yang terletak di pesisir utara pulau Jawa bagian timur, yang semula dengan masyarakat yang miskin maka kian hari dapat meningkatkan penghasilannya untuk memasarkan hasil laut dan makanan lainnya melalui internet. Kehidupan yang tradisional makin berubah dengan ciri-ciri perkotaan. BUMDes dapat memberikan andil besar untuk mendorong perubahan ekonomi masyarakat desa Drajat. Artikel ini pendekatannya secara kualitatif denga metode analisis kualitatif-deskriptif. Teknik pengumpulan data dengan wawancara mendalam terhadap informan Kepala Desa, Ketua Karang taruna, pengurus BUMDes, penggiat TIK dan nelayan,serta petani.Simpulannya, telah terjadi perubahan social yang gradual pada masyarakat desa Drajat ke arah ciri-ciri masyarakat perkotaan dengan makin massif intervensi internet.
\end{abstract}

\title{
Kata Kunci: Internet, perubahan sosial, daerah pesisir
}

\section{PENDAHULUAN}

Kajian mengenai peran media dalam proses perubahan sosial pada suatu wilayah pedesaan,daerah tertinggal atau terbelakang, telah banyak dilakukan orang. Peran media konvensional dapat menjadi faktor yang mempengaruhi perubahan norma dan nilai dalam masyarakat bila dilakukan terpaan media secara kontinu. Fungsi komunikasi massa, menurut Sean 
MacBride,Ketua Komisi Masalah-Masalah Komunikasi UNESCO (dalam Cangara,1998:63) dapat memenuhi fungsi informative; fungsi sosialisasi,memotivasi,bahan diskusi; fungsi edukasi; memajukan kebudayaan; fungsi hiburan; dan fungsi integrasi.

Lebih jauh Wiryanta (2000) menyatakan bahwa pendapat Schramm pada dasarnya tidak berbeda dengan pendapat Harold. D Laswell yang menyebutkan fungsi-fungsi komunikasi massa adalah : (1) Surveillance of the environment, yaitu berfungsi sebagai pengamat yang oleh Schramm disebut sebagai decoder yang menjalankan fungsi the watcher. (2) Correlation of the parts of society in responding to the environment, berfungsi untuk menghubungkan bagian-bagian dari masyarakat agar sesuai dengan lingkungan. Schramm menamakan fungsi ini sebagai interpreter yang melakukan fungsi the forum. (3) Transmission of the social heritage from one generation to the next, berfungsi menyebarkan atau meneruskan warisan social dari satu generasi ke generasi selanjutnya. Schramm menamakan fungsi ini sebagai encoder yang menjalankan the teacher.

Bila proses komunikasi menjalankan fungsi-fungsinya maka dapat dikatakan media sebagai sarana penyebaran informasi telah berperan dengan baik.Konten dari informasi perubahan yang disebarluaskan,akan dapat mempengaruhi masyarakat untuk dapat berubah dengan berbagai factor yang mendasarinya. Dengan dengan komunikasi memberi efek yang diinginkan,diantaranya perubahan social (Yuni Mogot,2021:8). 
Suatu hasil studi yang cukup monumental dapat memberi makna dari peran komunikasi dalam perubahan social. Daniel Lerner tahun 1958 telah menulis hasil studi The Passing of Traditional Society,yang telah diterjemahkan Memudarnya Masyarakat Tradisionil ( Gadjah Mada University Press, 1978). Diantara hasil studinya bahwa interaksi yang terus menerus dari pedesaaan/tradisional dengan kehidupan perkotaan dalam arti sering berkomunikasi,maka dapat menularkan efek modernisasi. Dan virus kemauan manusia untuk berubah juga menjadi factor penting untuk dapat meraih kemajuan. Kasus yang diteliti di Turki,Libanon,Mesir ,Siria ,Yordania dan Iran. Negara-negara itu sekarang ini masyarakatnya telah berkembang sebagai negara modern dan maju teknologi komunikasinya.

Kasus yang lebih spesifik dalam tulisan ini mengenai peran media baru (Internet) yang telah masuk dapat diakses pada suatu daerah,telah mempengaruhi dan merubah kehidupan social ekonomi masyarakat tersebut,seperti di desa Drajat di pesisir pantai utara Pulau Jawa bagian timur.

Sementara itu media baru perkembangan teknologi informasi Internet sudah makin maju dan canggih. Pemanfaatannya makin massif dilakukan masyarakat, sektor pemerintah dan swasta. Dengan demikian, masyarakat telah memasuki era informasi dengan teknologi digital. Leslie David Simon, pakar senior tentang kebijakan dan mantan eksekutif IBM, Amerika Serikat, dalam bukunya berjudul Demokrasi dan 
Internet- Kawan atau Lawan? (Yogyakarta: Tiara Wacana,2003) menegaskan bahwa internet dapat memberdayakan warga dan konsumen dengan menyediakan pengetahuan dan alat baru untuk mengimbangi pemerintah dan institusi besar lainnya. Bahkan internet dapat membuat pemerintah transparan dan terbuka untuk diawasi.

Dijelaskan lebih jauh, di Amerika Serikat, pemerintahan di semua level menempatkan informai secara online, sehingga warga negara dapat mengaksesnya 24 jam selama seminggu. Dalam perspektif politik, maka hari ini kita tahu bahwa internet jelas memberikan alat baru yang kuat untuk demokrasi dan juga dapat meningkatkan kesejahteraan ekonominya.

Kemudian dalam perspektif pembangunan social, dengan kehadiran media baru berupa internet dengan berbagai platform yang dapat diakses public atau masyarakat, paling tidak ekspose informasi sudah sampai kepada masyarakat. JandyLuik (2020:2) menjelaskan istilah media baru memiliki makna pada medium yang bernuansa digital, terkoneksi dan interaktif , institusi media berbasis digital atau pengembangan dari media analog, dan menawarkan progress dalam berbagai aspek kehidupan manusia.

Dalam konsep perubahan social, maka intervensi internet ini tergolong pada perubahan social yang direncanakan,sehingga dapat diantisipasi ruang lingkup perubahan social yang bakal terjadi daam masyarakat tersebut. Namun dibandingkan bila terjadi suatu bencana alam, seperti gempa bumi, maka perubahan social 
yang terjadi dapat dikategorikan sebagai perubahan social yang tidak direncanakan.

Berkaitan dengan perubahan social, dalam komunikasi pembangunan telah memberi peran yang strategis pada media massa untuk melakukan perubahan social dalam masyarakat. Keberadaan media massa dan masyarakat dapat dilihat secara timbal balik. Secara konseptual terdapat dua pandangan, apakah media membentuk atau mempengaruhi masyarakat, ataukah sebaliknya sebagai cermin atau dipengaruhi oleh realitas masyarakat. (Wiryanto, 2011: 12)

Dalam masyarakat yang berkembang modern dewasa ini, relasi manusia dengan media baru semakin intim. Penggunaan internet, baik dalam kehidupan professional maupun pribadi semakin tinggi. Internet juga menjadi bagian yang tak terpisahkan dalam kehidupan sehari-hari, baik di ruang kerja public maupun masyarakat (Kurnia, 2019:3). Dengan demikian dapat dikatakan, dalam masyarakat yang berdekatan dengan perkotaan, maka telah terjadi relasi yang intensif pemanfaatan Internet dan proses komunikasi ke arah perubahan social.

Rumusan masalah bagaimanakah media baru (internet) dapat berperan untuk mendorong perubahan social dalam masyarakat desa pesisir di desa Drajat? Faktor-faktor apa yang menjadi pengaruh terhadap terjadinya perubahan social tersebut? 


\section{METODE PENELITIAN}

Tulisan ini berupa catatan lapangan bertujuan untuk menuliskan data dan fakta dengan pendekatan kualitatif, dan metode penelitian kualitaif. Penelitian kualitatif (Moeleong, 2006:7) bermaksud untuk memahami fenomena tentang apa yang dialami oleh subyek penelitian, misalnya perilaku, persepsi, tindakan dan lain-lain; secara holistic,dengan cara deskripsi dalam bentuk kata-kata dan bahasa pada suatu konteks khusus yang alamiah dan dengan memanfaatkan berbagai metode alamiah.

Creswell (dalam Raco, 2010) metode penelitian kualitatif sebagai suatu penelusuran untuk mengeksplorasi dan memahami suatu gejala sentral.Teknik pengumpulan data dengan wawancara mendaalam (indepth-interview) kepada 5 informan dan observasi di lapangan. Informan dari perangkat Desa Drajat, pengurus Karang Taruna, nelayan, pegawai BUMDes dan penggiat TIK.

Teknik analisis secara deskriptif-kualitatif. Tujuan catatan penelitian ini untuk melengkapi laporan yang utuh dari penelitian 'Pemanfaatan TIK untuk pengentasan kemiskinan', yang dikerjakan Puslitbang Aptika IKP,Badan Litbang SDM, Kemkominfo, Jakarta bekerjasama dengan Lembaga Penelitian dan Pengabdian Masyarakat (LPPM) Universitas Brawijaya, Malang. Catatan ini mengambil lokasi penelitian ini di desa Drajat, Kecamatan Paciran, Kabupaten Lamongan,Provinsi Jawa Timur. Pengumpulan data selama 3 hari, tanggal 6 sampai 8 September 2017. 


\section{PEMBAHASAN}

Desa Drajat yang terletak di pesisir utara pulau Jawa masuk dalam wilayah propinsi Jawa Timur. Masyarakat desa pesisir ini bermata pencaharian nelayan dan juga bercocok tanam di sawah. Namun dalam sepuluh tahun terakhir ini (2017) telah terjadi pergeseran norma dan pola kehidupan masyarakat pesisir desa Drajat yang masih banyak berpenghasilan rendah atau miskin. Faktor yang dominan dapat ditengarai makin kuatnya intervensi jaringan internet di desa itu. Masyarakat makin banyak yang memanfaatkan komputer dan juga handphone untuk berkomunikasi sehari-hari.Dapat pula kemungkinan faktor pembangunan fisik di wilayah sekitar desa yang makin banyak terjadi alih fungsi lahan dengan berdirinya lokasi pabrik-pabrik dan perumahan baru yang bakal membentuk susunan masyarakat dengan ciri-ciri perkotaan.

Desa Drajat lokasinya tidak jauh dari kota Surabaya yang merupakan ibukota Jawa Timur.Penduduk desa Drajat sebagian besar sebagai nelayan dan petani. Para nelayan mencari ikan di pantai Lamongan hingga ke selat Bali dan pantai Muncar di Banyuwangi, dengan perahu kecil yang memuat 10 hingga 20 orang. Jarak desa Drajat dengan kota Surabaya sekitar $70 \mathrm{~km}$ yang ditempuh dengan kendaraan sekitar1 jam 30 menit. Kondisi jalan raya negara sangat baik. 


\section{A. Deskripsi Pesisir Desa Drajat}

Batas-batas wilayah desa Drajat, disebelah utara berbatasan dengan desa Banjaranyar, sebelah barat dengan desa Kranji sebelah timur dengan desa Kemantren dan di sebelah selatan berbatasan dengan desa Banjarwati. Luas wilayah Drajat sekitar 10 ha, dengan jumlah 10 RT dan 3 RW.

Nama desa Drajat lebih dahulu ada sebelum terdapatnya makam salah satu dari 9 Sunan yang menyebarkaan agama Islam di pulau Jawa, yang dikenal sebagai 'Wali Songo' yaitu Sunan Drajat. Pengaruhnya agama Islam cukup kental dianut penduduk desa Drajat.

Jumlah penduduk desa Drajat sekitar 2076 jiwa dengan jumlah KK sekitar 542 KK. Terdapat madrasah 2 yaitu Madrasah Ibtidaaiyah Tarbiyatul Atfal dan PAUD. Masjid 2 buah yaitu masjid Almubarok di Alun-alun desa Drajat, dan masjid perumahan Graha Indah Paciran masjid Almuhajirin.

\section{B. Fungsi Komunikasi}

Komunikasi dalam pengertian umum merupakan aktifitas menyampaikan pesan dari satu pihak ke pihak lain, dan pihak yang dimaksud bisa seseorang perorangan, bisa sekelompok orang dalam bentuk organisasi formal atau informal atau banyak orang yang sifatnya massif. Komunikasi bisa disampaikan langsung bisa melalui saluran komunikasi. Pihak lainnya, ialah sebagai penerima 
pesan, juga bisa satu orang atau banyak orang baik kelompok tertentu atau massa.

Fiske (1992) mengemukakan ada dua perspektif komunikasi, yaitu perspektif proses dan perspektif semiotic. Dalam perspektif proses, komunikasi dipandang sebagai sebuah proses penyampaian pesan komunikasi dari komunikator ke komunikan melalui proses linier. Makna pesan yang disampaikan kepada komunikan sudah pasti dan tidak memiliki makna lain, komunikan akan menerimanya sebagaimana yang disampaikan komunikator.

Pada perspektif yang kedua ialah melihat proses komunikasi merupakan proses penandaan atau semiotic. Perspektif ini, menganggap proses komunikasi bukanlan proses yang linier, pihak komunikator dengan komunikan berada tidak pada posisi setara dan memiliki kekuatan penuh dalam mengendalikan media. Pesan yang disampaikan tidaklah memiliki makna yang tetap tetapi bisa banyak makna tergantung konteks si penerima dalam pemahamannya. Artinya makna isi komunikasi adalah policemy, dan dalam perspektif ini pula terdapat pihak yang memiliki kuasa lebih atau dominan.

Kemudian, proses komunikasi juga dapat dipahami dengan model komunikasi interaksional DeFleur (dalam Suprapto,2019: 20) bahwa proses komunikasi tidak semata bersifat linear tetapi mengarah pada sifatnya yang sirkuler yakni ditandai dengan adanya kompone umpan balik. 
Model komunikasi linier yang menjadi popular dan sering dijadikan acuan adalah model Lasswell (dalam Waston, 1996) yang mengembangkan proses dalam bentuk pertanyaan, who, says what, in which channel, to whom and with what effect. Dengan model ini, pihak komunikator secara linier mendistribusikan pesan kepada komunikan melalui saluran komunikasi tertentu dan akan menimbulkan efek tertentu kepada komunikannya.

Model lain yang merupakan model yang mendapat pengaruh Lasswell, ialah model Gerbner (dalam Waston, 1996), yang mengemukakan 10 pernyataan yaitu someone perceives an event and reacts in a situation thtouh some means to make available materials in some form and context conveying content with some consequence. Kedua model tersebut masih tergolong dalam paradigma proses, perbedaannya jika pada model Lasswell, proses dimulai pihak penyampaikan dan yang menentukan ialah pihak komunikator yang menyampaikan pesan. Dengan demikian efek yang terjadi dari suatu tindak komunikasi ditentukan oleh kualitas komunikator dalam menyampaikan pesan, kualitas pesan dan kualitas salurannya. Sedangkan dalam model Gerbner, penggambaran proses dimulai dari pihak penerima atau komunikan dalam menerima suatu pesan, sehingga factor yang menentukan terjadinya efek (istilah Gerbner Konsekuensi) atau kualitas efek ditentukan oleh komunikan dan lingkungannya, antara lain apakah komunikan memiliki kemampuan untuk menjangkau media, bagaimana konteks ketika menerima pesan 
dari komunikan. Artinya factor factor yang perlu diperiksa apakah tindak komunikasi bisa berhasil atau tidak dilihat dari kondisi komunikan dan lingkungannya.

Secara lebih rinci, Goran Hedebro, seorang doctor ilmu komunikasi berkebangsaan Swedia dalam bukunya Communication and Social Change in Developing Nations (dalam Cangara, 1998: 65) mengemukakan bahwa fungsi komunikasi massa,ditujukan untuk : (1) Menciptakan iklim perubahan dengan memperkenalkan nilai-nilai baru untuk mengubah sikap dan perilaku kea rah modernisasi; (2) mengajarkan keterampilan baru;(3) berperan sebagai pelipat ganda ilmu pengetahuan; (4) menciptakan efisiensi tenaga dan biaya terhadap mobilitas seseorang; (5) meingkatkan aspirasi seseorang;(6) menumbuhkan partisipasi dalam pengambilan keputusan terhadap hal-hal yang menyangkut kepentingan orang banyak; (7) membantu orang menemukan nilai baru dan keharmonisan dari suatu situasi tertentu; (8) mempertinggi rasa kebangsaan; (9) meningkatkan aktivitas politik seseorang; (10) mengubah struktur kekuasaan dalam suatu masyarakat; (11) menjadi sarana untuk membantu pelaksanaan program-program pembangunan; (12) mendukung pembangunan ekonomi,social,dan politik suatu bangsa. Dengan demikian,dari perspektif paradigma positivistic, media komunikasi massa mampu mendorong atau menciptakan perubahan social dalam masyarakat. 


\section{Konsep Perubahan Sosial}

Secara teoritis, dinamika sosial dan perubahan sosial yang terjadi dalam suatu masyarakat dapat ditelaah secara akademis. Artinya perubahan sosial yang terjadi juga dapat diamati dari konsep-konsep yang banyak diajukan para ilmuwan sosial, terutama dari perspektif sosiologi. Perubahan-perubahan yang terjadi di dalam masyarakat pada umumnya menyangkut hal yang kompleks. Sosiolog Prof. Dr. Selo Soemardjan memberikan pengertian perubahan sosial adalah segala perubahan pada berbagai lemabaga masyarakat dalam suatu lingkungan masyarakat yang mempengaruhi sistem sosial, termasuk didalamnya nilai sosial, sikap, pola perilaku antara kelompokkelompok dalam masyarakat. (https://blog.ruangguru.com/7pengertian-perubahan-sosial-menurut-para-ahli)

Sementara itu, Kingsley Davis mengartikan perubahan sosial sebagai perubahan-perubahan yang terjadi dalam struktur dan fungsi masyarakat.(https://blog.ruangguru.com/7-pengertianperubahan-sosial-menurut-para-ahli). Bila mengambil contoh perubahan yang direncanakan merujuk pada peran media dan perubahan social (Maryani, 2011: 105) kasus radio komunitas Angkringan di Timbulharjo, Yogyakarta yang memanfaatkan radio komunitas untuk mendorong perubahan kea rah kehidupan demokratis dan social ekonomi bagi masyarakat local.

Kehadiran teknologi memberikan pengaruh sangat besar dalam kehidupan manusia.Marshall McLuhan,seorang pemikir 
bangsa Kanada,melalui bukunya Understanding Media (dalam Morissan,2010: 30) menulis mengenai pengaruh teknologi,khususnya teknologi komunikasi, menunjukkan bahwa teknologi membentuk perasaan,pikiran dan tindakan manusia. Pemikiran ini disebut technological determinism yaitu teknologi bersifat determinan (menentukan) dalam membentuk kehidupan manusia. Dengan demikian, internet dapat mendorong perubahan social dalam masyarakat.

Adapun bentuk dari perubahan sosial itu dapat terjadi dengan perubahan yang direncanakan dan perubahan yang tidak direncanakan. Dalam kasus di desa Drajat, pada hakikatnya merupakan bentuk perubahan yang direncanakan. Penetrasi Internet yang sesungguhnya merupakan bentuk perubahan yang direncanakan dalam level nasional. Dampak-dampak yang timbul dari penetrasi Internet yang global, yang juga akan merubah tatanan masyarakat yang terkena penetrasi Internet. Dan proses perubahan itu apakah akan berlangsung lambat atau cepat, yang akan mempengaruhi kehidupan sosial masyarakat. Dengan demikian, dapat dikatakan, komunikasi merupakan elemen dasar yang menggerakkan masyarakat. Komunikasi menjadi elemen social penggerak masyarakat yang secara temporan berevolusi untuk melahirkan fungsi-fungsi dalam masyarakat secara terdiferensiasi atau fungsi-fungsi yang membedakan (Wahyuni, 2020:2). 


\section{Gambaran Demografi}

Menurut data 2016 disebutkan jumlah penduduk Desa Drajat 2076 jiwa dengan jumlah KK 542 KK. Namun pada tahun 2014 Jumlah penduduk desa Drajat mencapai 2.150 jiwa yang tersebar di 1 Dusun, 3 RW dan 10 RT. Dari jumlah tersebut, terdiri dari laki-laki 1.096 jiwa dan perempuan 1.061 jiwa. Perkembangan jumlah penduduk di desa drajat dalam 6 (enam) tahun terakhir dapat dilihat pada tabel berikut:

Tabel 1.Perkembangan Kependudukan Tahun 2009. - 2015

\begin{tabular}{|c|c|c|c|c|c|c|c|}
\hline Uraian & $\begin{array}{c}\text { Satu } \\
\text { an }\end{array}$ & 2009 & 2010 & 2011 & 2012 & 2013 & 2014 \\
\hline Luas Wilayah & $\mathrm{km}^{2}$ & 31,85 & 31,85 & 31,85 & 31,85 & 31,85 & 38,85 \\
\hline $\begin{array}{l}\text { Jumlah } \\
\text { Penduduk }\end{array}$ & jiwa & 1838 & & & 2.094 & 2.150 & 2.150 \\
\hline $\begin{array}{l}\text { Jumlah Laki- } \\
\text { Laki }\end{array}$ & jiwa & 720 & & & 1096 & 1096 & 1096 \\
\hline $\begin{array}{l}\text { Jumlah } \\
\text { Perempuan }\end{array}$ & jiwa & 522 & & & 1061 & 1061 & 1.061 \\
\hline $\begin{array}{l}\text { Jumlah A- } \\
\text { RTM } \\
\end{array}$ & orang & & & & & & \\
\hline $\begin{array}{l}\text { Pertumbuhan } \\
\text { Penduduk }\end{array}$ & $\%$ & & & & & & \\
\hline $\begin{array}{l}\text { Kelahiran } \\
\text { Penduduk }\end{array}$ & jiwa & & & & & 32 & 32 \\
\hline $\begin{array}{l}\text { Kematian } \\
\text { Penduduk }\end{array}$ & jiwa & & & & & & \\
\hline $\begin{array}{l}\text { Kepadatan } \\
\text { Penduduk }\end{array}$ & $\begin{array}{l}\text { Jiwa/ } \\
\mathrm{km}^{2}\end{array}$ & 38 & 38 & 38 & 38 & 38 & 39 \\
\hline
\end{tabular}

Sumber : profil drajat

Adapun penduduk tersebar di seluruh RT yang ada di Desa

Drajat. Berikut merupakan sebaran penduduk menurut data tahun 2015 
Tabel 2. Data Sebaran Penduduk Desa Per Wilayah tahun 2015

\begin{tabular}{|l|r|r|r|}
\hline \multirow{2}{*}{ Wilayah } & \multicolumn{2}{|c|}{ Penduduk } & \multirow{2}{*}{ Jumlah } \\
\cline { 2 - 3 } & Lk. & Pr. & \\
\hline \multicolumn{4}{|c|}{ RW. 001 } \\
\hline RT. 001 & 138 & 129 & 267 \\
\hline RT. 002 & 107 & 119 & 226 \\
\hline RT. 003 & 175 & 155 & 330 \\
\hline \multicolumn{5}{|c|}{ RW 002 } \\
\hline RT.001 & 103 & 109 & 212 \\
\hline RT.002 & 101 & 104 & 205 \\
\hline RT.003 & 90 & 142 & 232 \\
\hline & \multicolumn{4}{|c|}{ RW.003 } \\
\hline RT.001 & 76 & 111 & 155 \\
\hline RT.002 & 107 & 125 & 218 \\
\hline RT.003 & 112 & \\
\hline
\end{tabular}

Sumber: profil desa

\section{E. Gambaran Sosiologis}

Penduduk Desa Drajat sebagian besar memeluk agama Islam. Ini dikarenakan Desa Drajat merupakan pusat dari penyebaran Agama Islam sejak jaman dahulu. Di wilayah ini terdapat makam Sunan Drajat yang merupakan salah satu wali dari 9 wali penyebar agama Islam di Pulau Jawa. Selain adanya keberadaan makam sunan, juga terdapat pondok pesantren yang bersebelahan dengan Desa Drajat, yakni Pondok Pesantren Sunan Drajat. Pondok ini diasuh oleh KH. Ghofur yang merupakan salah satu ulama berpengaruh di kawasan Lamongan dan Gresik. Selain itu, terdapat pula Pondok Tarbiyatut Tholabah di Desa Kranji yang bersebalahan dengan Desa Drajat. Dulunya pondok ini juga

memiliki pengasuh yang menjadi ulama berpengaruh di Lamongan, yakni alm. KH Baqir Adlan. Di Desa ini terdapat satu Madrasah Ibtidaiyah, satu Pendidikan Anak Usia Dini, dan dua 
masjid besar, yakni Masjid Al Mubarok di kawasan alun-alun desa dan Al Muhajirin di kawasan perumahan Graha Indah Paciran.

Sebagian besar penduduk Desa Drajat merupakan alumni dua pondok besar tersebut. Mereka kemudian menggunakan ilmu agama yang didapat untuk kehidupan sehari-hari. Karena itu, masyarakat Desa Drajat hingga kini tergolong masyarakat yang religius. Selain itu, masyarakat di Desa Drajat juga bisa dikatakan sebagai masyarakat terpelajar. Sebagian besar penduduk pernah mengenyam pendidikan baik dalam pendidikan formal maupun pesantren. Setidaknya terdapat kurang lebih 790 penduduk yang pernah mengenyam pendidikan formal, minimal mengenyam pendidikan 9 tahun. Berikut merupakan data sumber daya manusia di Desa Drajat:

Tabel 3. Daftar Sumber Daya Manusia di Desa Drajat

\begin{tabular}{|c|c|c|c|}
\hline No. & Uraian Sumber Daya Manusia & Volume & Satuan \\
\hline 1. & Penduduk tamat SLTP atau sederajat & 472 & orang \\
\hline 2 & Penduduk tamat SLTA atau sederajat & 230 & orang \\
\hline 3 & Penduduk tamat D-1 & 5 & orang \\
\hline 4 & Penduduk tamat D-2 & 4 & orang \\
\hline 5 & Penduduk tamat D-3 & 11 & orang \\
\hline 6 & Penduduk tamat S-1 & 56 & orang \\
\hline 7 & Penduduk tamat S-2 & 12 & orang \\
\hline 8 & Penduduk tamat S-3 & - & orang \\
\hline
\end{tabular}

Sumber: data desa

Produk budaya atau tradisi kebudayaan di Desa Drajat juga kental dengan nuansa islami. Terdapat tradisi tahunan/periodik dan tradisi sehari-hari/rutinan yang ada di Desa Derajat. Pada tabel berikut merupakan daftar produk budaya yang ada di Desa Drajat: 
Tabel 4. Daftar Sumber Daya Sosial Budaya di Desa Drajat

\begin{tabular}{|c|l|c|c|}
\hline No. & \multicolumn{1}{|c|}{ Uraian Sumber Daya Sosial Budaya } & Volume & Satuan \\
\hline 1. & Makam Sunan Drajat & 1 & - \\
\hline 2. & Haul Sunan Drajat & 7 & Hari \\
\hline 3. & Hadroh Al Banjari & 1 & Grup \\
\hline 4. & Kentrung & 1 & Grup \\
\hline 5. & Macapat & 1 & Orang \\
\hline 6. & Karawitan & 1 & Grup \\
\hline
\end{tabular}

Sumber: monografi desa

Biasanya tradisi itu kini digerakkan oleh anak-anak muda Desa Drajat yang memiliki kepedulian untuk mempertahankan budayanya. Menurut Susan (2017) sebagai Ketua Karang Taruna Desa Drajat, bahwa saat ini budaya asli Desa Drajat mengalami pergeseran. Ia menyatakan salah satu penyebabnya adalah modernisasi yang begitu cepat. Saat ini beberapa pemuda sudah tidak lagi tertarik untuk mengikuti budaya-budaya desa yang menurutnya tergolong budaya religi.

Kerukunan di Desa Drajat tergolong kuat. Aspek religiusitas menjadikan masyarakat menjalin kerukunan antara satu sama lain. Biasanya terdapat ruang pertemuan yang dijadikan agenda menjalin kerukunan setiap pekannya, seperti pengajian. Akan tetapi, di Desa ini juga terdapat potensi konflik antar masyarakat. Tyo (2017) menjelaskan bahwa konflik pernah terjadi ketika Lomba 17 Agustusan pada beberapa tahun lalu. Konflik terjadi karena adanya kecemburuan dari beberapa pihak yang kalah karena merasa tidak diuntungkan atas hasil dewan juri. Namun konflik tersebut hanya pada skala kecil, berlangsung singkat, tidak menimbulkan korban, namun hanya terjadi sedikit kerusakan. 


\section{F. Gambaran Ekonomi dan Kesejahteraan Penduduk}

Berdasarkan hasil dari pengamatan peneliti dan pernyataan narasumber sebagian besar masyarakat di Desa Derajat bekerja sebagai Nelayan, Petani, Pedagang, Buruh Bangunan, Guru, dan Pengusaha. Sebagian pula, aktivitas ekonomi masyarakat Desa Drajat bergantung pada wisata religi Sunan Drajat. Di areal wisata tersebut terdapat toko-toko dan pedagang asongan.

Dulunya Desa Drajat merupakan tanah perdikan atau wilayah yang diberi keistimewaan khusus oleh Kerajaan Mataram Islam. Tanah perdikan berarti bahwa Desa Drajat tidak diberikan kewajiban untuk membayar pajak pada kerajaan. Keberadaan makam Sunan Drajat juga menjadi potensi ekonomi yang dimanfaatkan oleh masyarakat. Beberapa masyarakat disana ada yang berdagang di toko dan adapula yang menawarkan jasa penginapan.

Para nelayan biasanya langsung menjual ikan yang dibawa dari laut ke Tempat Pelelangan Ikan (TPI). Para nelayan di Desa Drajat melaut dengan sistem Kursinan (perahu besar yang muat sekitar 30-40 orang). Mereka melaut hanya dalam waktu sehari, biasanya pagi sekali berangkat kemudian sore atau malam sudah kembali. Jika untung mendapatkan ikan, jumlah penghasilan buruh nelayan bisa mencapai angka 100 ribu. Namun jika tidak, mereka bahkan hanya mendapatkan uang 10 ribu. Biasanya mereka berlayar dalam seminggu kurang lebih tiga kali, jika kondisi cuaca sedang bagus. Namun apabila kondisi cuaca sedang tidak bagus 
maka otomatis perahu diharuskan menepi. Biasanya, mereka beralih profesi menjadi buruh bangunan, adapula yang kemudian menjadi buruh serabutan.

Pertanian di Desa Drajat hanya menjadi aktivitas ekonomi sekunder. Lahan pertanian di Desa Drajat cukup kecil dan menerapkan sistem tadah hujan. Sebagian besar petani, menggunakan hasil panen untuk disimpan sebagai sarana kebutuhan makan sehari-hari. Kecuali pada saat musim tanam jagung, biasanya mereka menjual jagung tersebut. Akan tetapi, hasil dari penjualannya menurut mereka bisa disebut tidak signifikan.

Di Desa Drajat juga terdapat buruh pabrik dan buruh bangunan. Biasanya jika buruh pabrik dibayar dengan gaji UMR Kabupaten Lamongan, yakni pada tahun 2017 pada angka Rp.1.702.777. Jumlah pabrik di sekitar daerah Derajat atau di wilayah Kecamatan Paciran meningkat sejak tahun 2011. Terdapat pabrik-pabrik dalam skala besar seperti PT. Lamongan Marine Industry, Lamongan International Shorbase, pabrik sarden, dan pabrik reparasi kapal, pabrik olahan batu kapur, dan beberapa pabrik lainnya. Sedangkan untuk buruh bangunan biasanya dibayar 500 ribu per pekan.

Pedagang di Desa Drajat terdiri dari pedagang skala besar dan kecil. Para pedagang besar biasanya memiliki gerai di pinggir jalan Daendles. Sedangkan pedagang dalam skala kecil berada di lingkungan Desa Drajat. Penghasilan mereka begitu variatif, jika 
pedagang kecil kebanyakan di bawah 1 juta per bulan, namun pedagang besar bisa diatasnya. Pengusaha di Desa Drajat beberapa diantaranya merupakan pengusaha yang bergerak dari olahan hasil laut. Seperti para pengusaha krupuk dan terasi. Para pengusaha ini relatif masih muda dan masih baru memulai usahanya. Penghasilannya juga masih variatif berada di kisaran angka 500 ribu hingga kisaran 1 juta rupiah per bulan.

Terdapat pula pegawai swasta seperti guru madrasah dan perangkat desa. Dari beberapa narasumber yang notabenya sebagai guru menyatakan gaji mereka tidak terlalu besar. Guru madrasah mendapatkan gaji per bulan di bawah 1 juta atau di sekitar angka 1 juta. Sehingga, biasanya para pegawai atau guru yang berada pada lingkup desa ini memiliki usaha sampingan untuk menambah pendapatan mereka.

\section{G. Pemerintahan Desa}

Saat ini Kepala Desa Drajat di jabat oleh Ahmad Nailul Fauzi. Ia memimpin Desa Drajat untuk kedua kalinya. Adapun sebagai Ketua BPD adalah Baharudin. Sementara itu, sebagai Sekretaris Desa adalah Nurul Muttaqin.

Adapun visi dari dari Pemerintah Desa Drajat tahun 20162021 ialah; "Tercapainya Masyarakat Desa Drajat yang Religius, Sejahtera, Aman dan Damai." Sebagai misinya adalah:

1. Mewujudkan Tata Kelola Pemerintahan Desa yang Baik. 
2. Meningkatkan Pelayanan Pemenuhan Hak hak Dasar Rakyat.

3. Pembangunan Infrastruktur Dasar.

Pada arah pembangunannya Desa Drajat kini juga fokus pada peningkatan ekonomi desa melalui kegiatan usaha dari BUMDes Pemaring. Sebagai direktur dari badan tersebut ialah Tyo. BUMDes Pemaring memilik banyak unit usaha yang beberapa diantaranya ialah BUM Des Mart, produk unggulan desa, percetakan, mainan anak-anak, persampahan, pembayaran rekening listrik dan air, dsb.

\section{H. Infrastruktur TIK}

Perkembangan Infrastruktur TIK di Desa Drajat sudah baik. Hal ini dibuktikan dengan keberadaan jaringan telekomunikasi di Desa Drajat yang cukup kuat, beberapa diantara operator telekomunikasi, ialah: Telkomsel, Indosat, XL Axiata, dll. Keberadaan operator ini telah menunjang kegiatan telekomunikasi masyarakat berupa telepon dan SMS. Masyarakat dulunya juga sempat memanfaatkan telpon rumah yang dilayani oleh Telkom. Namun seiring berkembangnya waktu, kini keberadaan telpon rumah tersebut telah digantikan oleh Handphone.

Selain itu, jaringan televisi dan radio di Desa Drajat juga cukup baik. Hampir di setiap rumah masyarakat dan ruang publik terdapat televisi. Sedangkan, radio mulai ditinggalkan oleh 
masyarakat. Keberadaan radio telah ditinggalkan dikarenakan adanya fasilitas internet yang telah masuk di Desa Drajat.

Jaringan internet di Desa Drajat sudah pada kualitas 3G. Kebanyakan masyarakat mengakses operator IM3 dikarenakan harga paket internetnya yang murah. Sebagian pula memanfaatkan Simpati/As lantaran jaringannya yang bagus. Adapun sebagian kecil masyarakat juga memanfaatkan operator lain seperti XL dan AXIS.

Di Desa Drajat juga telah terfasilitasi dengan keberadaan jaringan internet kabel berupa Indihome. Beberapa tempat publik seperti warung kopi dan kantor desa menyediakan fasilitas wifi gratis pada masyarakat, atau pelanggan jika di warung kopi. Adapun juga terdapat dua layanan warung internet (warnet) di Desa Drajat. Saat ini keberadaan warnet mulai tidak banyak diakses masyarakat karena masyarakat cenderung menggunakan fasilitas internet yang ada di HP. Warnet sebagian besar hanya digunakan untuk game online.

Dulu, pada sekitar tahun 2006 terdapat fasilitas telecenter di Desa Drajat. Fasilitas ini digunakan untuk pelatihan MS Word dan Excel. Sebagian besar pesertanya adalah anak-anak sekolah yang sedang membutuhkan pengetahuan mengenai hal tersebut. Menurut Agus (2017), keberadaan telecenter pada waktu itu cukup bermanfaat karena telah mengenalkan masyarakat dengan dunia komputer dan internet. Karena selain berfungsi mengadakan pelatihan, telecenter juga berfungsi sebagai warnet. Banyak 
masyarakat, terutama anak-anak muda, baik dari Desa Drajat atau dari luar desa yang pada waktu itu datang ke telecenter untuk mengakses internet.

Akan tetapi, saat ini telecenter tersebut telah mati. Perangkat-perangkatnya telah tidak berfungsi dan di letakkan di ruang karang taruna. Agus (2017) menceritakan bahwa telecenter waktu itu semakin sepi dan jarang aktivitasnya pada sekitar tahun 2008-2010. Hal ini dikarenakan telah ditariknya sejumlah bantuan pemerintah terkait pemeliharaan dan fasilitas terhadap telecenter. Selain itu, dikarenakan masyarakat telah banyak yang mengakses internet melalui smartphone pada tahun 2010 keatas. Terdapat pula warnet yang menjadi pesaing dari keberadaan telecenter. Saat ini, hanya ada satu perangkat yang dimodifikasi kemudian digunakan oleh Karang Taruna Desa Drajat.

Untuk kebutuhan melaut beberapa perahu saat ini juga dilengkapi dengan peralatan GPS, Fish Finder, dan pendeteksi karang. Alat itu biasanya dimiliki oleh pemilik perahu sebagai sarana untuk memudahkan mereka ketika melaut. Peralatan tersebut cukup membantu meski harganya tidak murah. Oleh sebab itu, alat ini tidak banyak dimiliki oleh banyak perahu.

\section{Kondisi TIK}

Sebagian besar penduduk di Desa Drajat telah mengakses Teknologi Informasi dan Komunikasi. Saat ini, sebagian besar mereka mengakses teknologi berupa HP dan TV, sebagian kecil 
juga telah memanfaatkan laptop/PC. Pun demikian dengan penduduk miskin di Desa Drajat, sebagian besar mereka telah memiliki HP dan TV. Adapun kegunaan HP tersebut digunakan untuk menerima dan mencari informasi serta untuk sarana komunikasi. Sedangkan untuk fasilitas internet yang biasanya terdapat dalam layanan smartphone biasanya digunakan oleh penduduk pada usia muda di bawah umur 40 tahun. Sedangkan penduduk diatas 35 tahun yang utamanya bekerja sebagai nelayan, petani, atau buruh sebagian besar hanya memanfaatkan fasilitas komunikasi berupa telpon dan SMS yang ada dalam fasilitas HP.

Semua informan penduduk miskin dalam penelitian ini telah memiliki sarana TIK. Mereka memanfaatkan TIK dalam kegiatan yang begitu variatif. Niken, menggunakan sarana TIK seperti televisi, laptop/PC dan smartphone. Menurut intensitasnya, ia lebih sering memakai HP dan TV. Penggunaan TV lebih sering ia gunakan untuk hiburan dan menerima informasi melalui berita. Sedangkan untuk smartphone digunakan oleh Niken untuk media komunikasi dengan suami, keluarga, dan teman-temannya. Ia juga aktif berselancar melalui internet untuk aktif di media sosial, mencari informasi, dan untuk hiburan. Untuk pulsa Niken biasanya menghabiskan kurang 50 ribu per bulan. Sebagian besar pulsa tersebut habis untuk kegiatan telpon. Terkait mencari informasi, Niken memanfaatkan internet sebagai media belajar untuk mempelajari mengenai dunia usaha berbasis IT dan produk olahan hasil laut. Ia menceritakan bahwa ia giat melihat saudaranya yang 
sukses melakukan bisnis online di Bandung. Akan tetapi, hingga saat ini Niken belum dapat mengembangkan bisnisnya melalui internet dikarenakan kesibukan mengurus anaknya yang masih bayi.

Nur Sodikin yang notabenya sebagai pegawai BUMDes juga telah mengakses TIK berupa komputer, TV, dan smartphone. Sodikin mengakses komputer milik BUMDes untuk kebutuhan layanan konsumen. Saat ini, ia sudah jarang menonton TV, dikarenakan sekarang menurutnya lebih efektif menggunakan smartphone dalam mengakses hiburan dan informasi. Di smartphone ia lebih banyak menggunakan aplikasi media sosial, seperti facebook, instagram, BBM, dan Whatsapp. Ia belum banyak memanfaatkan internet untuk kegiatan belajar atau bisnis online. "Soalnya saya berpikir media sosial itu hanya untuk kegiatan pribadi, mas. Bukan untuk aktivitas ekonomi. Tapi kalau mau dicoba untuk itu ya bisa juga, sih," ujar Sodikin. Dari pernyataan tersebut, Sodikin saat ini lebih cenderung menganggap bahwa layanan internet, khususnya media sosial, hanya baik digunakan untuk kebutuhan yang sifatnya komunikasi yang beriorientasi pada interaksi sehari-hari dan hiburan. Sementara untuk kegiatan ekonomi, ia belum memikirkan tentang itu. Setiap bulannya Sodikin menghabiskan pulsa kurang lebih 65 ribu rupiah. Namun Sodikin tidak memungkiri bahwa jika ada kemungkinan untuk mengembangkan usaha stik tepungnya melalui internet. 
Sebagai seorang nelayan yang berusia 38 tahun Ropiq juga mengakses TV dan smartphone. Ia mengatakan bahwa sekarang jarang nonton TV. Seringnya ia menggunakan fasilitas yang ada di smartphonenya. Untuk fasilitas dalam smartphone ia lebih banyak menggunkan layanan SMS, Telpon, dan media hiburan. Ia jarang menggunakan untuk kebutuhan media sosial, meski ia memiliki fasilitas WA di smartphonenya. Menurutnya ia tidak memiliki banyak waktu untuk mengakses fasilitas media sosial. Ia sering memanfaatkan media hiburan berupa pemutar musik dangdut, media pencarian untuk menginstal musik dan video, ataupun sesekali mengakses Youtube untuk melihat hiburan seperti dangdut. Ropiq lebih sering tidak memiliki paketan, terutama ketika ia masih belum memiliki pendapatan yang baik dalam setiap minggunya. Karena itu, ia lebih banyak memanfaatkan fasilitas SMS dan Telpon. Ia juga mengatakan tidak pernah sama sekali mengakses layanan internet sebagai media belajar atau bahkan memanfaatkan internet sebagai sarana untuk meningkatkan ekonomi. Menurutnya, waktunya tidak cukup untuk melakukan aktivitas tersebut.

Berbeda dengan informan lainnya Sigit dan Agus telah memanfaatkan TIK untuk kegiatan ekonomi. Sigit selama ini telah mengakses TIK berupa TV, komputer, dan smartphone. Untuk TV ia sudah jarang menggunakan. Ia lebih sering memanfaatkan komputer milik BUMDes Mart untuk layanan usaha dan smartphone. Menurutnya, selama ini ia sangat bergantung dengan 
smartphone untuk berkomunikasi dan mendapatkan informasi. Karena ia sebagai pelaku usaha di bidang penyewaan peralatan pesta. Biasanya ia berkomunikasi dengan para pengusaha peralatan pesta di media sosial berupa grup di WA. Di media tersebut ia bertukar informasi mengenai jenis-jenis terbaru perlengkapan beserta harganya, juga bertukar informasi mengenai kebutuhan sewa perlengkapan. Biasanya ia juga menanggapi pemesanan lewat grup tersebut. Selain itu, ia juga mencari informasi dan belajar sesuatu lewat internet atau media browser. Ia menggunakan fasilitas tersebut untuk mencari informasi lowongan kerja. Misalnya, beberapa waktu ini ia mencari informasi di internet mengenai lowongan pendamping desa. Ia juga kemudian mencoba untuk belajar bahan-bahan tes masuk pendamping desa melalui mesin pencarian Google. Biasanya Sigit menghabiskan pulsa kurang lebih 50 ribu per bulan. Untuk internet seringkali juga ia menikmati fasilitas layanan wifi gratis di Kantor Desa ataupun di watung kopi.

Agus mengakses TIK mulai dari TV, komputer/laptop, dan smartphone. TV ia gunakan untuk sebagai sarana untuk menerima informasi dari berita. Selebihnya TV hanya ia gunakan sebagai media hiburan. Sementara itu, komputer/laptop juga sering ia gunakan untuk kebutuhan mengerjakan tugasnya sebagai guru. Selama ini ia menggunakan laptop milik sekolah. Namun seperti informan lainnya, ia lebih sering menggunakan smartphone. Perangkat ini ia gunakan sebagai sarana mencari informasi dan 
kegiatan komunikasi. Ia juga memanfaatkan perangkat ini untuk kegiatan usahanya, meski dalam intensitas yang rendah. Ia menceritakan beberapa kali mempromosikan krupuk cuminya melalui grup WA guru-guru madrasah. Hasilnya beberapa guru sempat memesan produknya melalui grup tersebut. Ia juga pernah memasukkan produknya melalui FB dan Instagram, namun hasilnya tidak signifikan. Melalui internet ia juga belajar mengenai cara mengembangkan ekonomi. Seperti ia pernah mencoba belajar membikin bubur ayam. Untuk setiap bulannya kurang lebih Agus menghabiskan pulsa sekitar 50 ribu.

Dari beragam informasi dari informan tersebut dapat diketahui bahwa terdapat potensi pemanfaatan TIK untuk pengentasan kemiskinan di Desa Drajat. Hal ini ditunjang dengan kepemilikan TIK dan infrastruktur pendukung TIK yang ada di Desa Drajat. Akan tetapi, dikarenakan kurangnya pengetahuan dan skill masyarakat mengenai pemanfaatan TIK sebagai sarana peningkatan ekonomi membuat aktivitas ini masih jarang dilakukan.

Kondisi yang berbeda terjadi pada penduduk dengan kategori umur diatas 35 tahun yang bekerja menjadi buruh, misalnya buruh nelayan. Sebagaimana yang diungkapkan oleh Ropiq bahwa dirinya saat ini belum banyak memanfaatkan sarana TIK untuk kebutuhan mencari informasi atau kegiatan ekonomi. Meski ia tahu cara penggunaannya, ia menyatakan belum ada kebutuhan untuk mengembangkan ekonomi melalui internet. Ia 
juga mengatakan bahwa tidak ada waktu bagi dirinya untuk mengurusi aktivitas ekonomi melalui internet.

Sebagian besar informan menyatakan mendapatkan pengetahuan TIK melalui lembaga pendidikan formal. Mereka telah diajarkan mata pelakaran TIK di setiap sekolah masingmasing. Namun pada saat di sekolah pelajaran mengenai internet masih sangat sedikit sekali diajarkan. Sehingga aktivitas internet yang mayoritas diakses melalui smartphone diketahui melalui proses otodidak atau diberitahu oleh lingkungan sekitar seperti teman. Namun, bagi Ropiq dan Agus yang notabenya penduduk di usia 35 tahun keatas mengatakan dulu belum mendapatkan pelajaran mengenai TIK. Sehingga, mereka lebih banyak mengetahui perihal penggunaan teknologi secara otodidiak.

Semua informan juga menyatakan belum pernah mendapatkan pelatihan pemanfaatan TIK dari pemerintah maupun pihak swasta. Mereka mengatakan dulu pernah ada Telecenter yang juga memberikan fasilitas berupa pelatihan dan pemberian jasa internet. Namun mereka merasa belum pernah mendapatkan pelatihan karena pada waktu itu sebagian besar yang memanfaatkan pelatihan ada para pelajar. Sehingga beberapa menyebutkan hanya memanfaatkan jasa warnet dari telecenter. Kecuali Agus, ia merupakan pengelola Telecenter pada waktu itu.

Agus menjelaskan pada waktu itu sedikit masyarakat yang notabenya miskin mengikuti pelatihan. Ia juga lupa siapa masyarakat yang pada waktu itu mengikuti pelatihan. Yang ia ingat 
adalah para pelajar dari sekolah-sekolah yang waktu itu di sekolahnya belum terdapat komputer belajar di Telecenter. Begitupun pada aktivitas jasa internet di telecenter, ia menggambarkan pada waktu itu aktivitas warnet hanya dimanfaatkan mayoritas oleh kalangan muda baik dari luar atau anak muda Desa Drajat sendiri. Pada waktu itu, juga belum ada pelatihan pengentasan kemiskinan atau peningkatan bisnis/ekonomi melalui internet.

Mayoritas informan juga telah memanfaatkan grup di media sosial, salah satu yang paling digemari adalah grup WA. Mereka rata-rata menggunakan grup tersebut untuk berkomunikasi dengan anggota internal grup mengenai dunia hiburan dan perbincangan dalam nuansa keakraban atau dalam istilah lebih spesifik, bercanda.

Dari perspektif teoritis,mereka yang tergabung dalam grup WA dapat disebut sebagai suatu komunitas yang merupakan kumpulan dari berbagai individu yang disatukan oleh kesamaan. Kesamaan bisa muncul karena faktor geografis, etnisitas, agama, kultur, kegiatan maupun menggunakan media. Dalam media baru, komnitas virtual bisa terbentuk karena adanya jaringan yang menghubungkan diantara pengguna (Nasrullah,2018:33)

Apabila grup tersebut merupakan wadah komunikasi organisasi, biasanya grup tersebut digunakan untuk interaksi anggota yang berkaitan tentang aktivitas organisasi. Namun ketika coba digali informasi mengenai keberadaan grup WA yang 
menjaring para nelayan, buruh bangunan, dan petani para informan masih mengatakan belum mengetahui keberadaan info tersebut. Mereka menyangka bahwa kelompok kerja tersebut masih belum banyak memanfaatkan jejaring grup media sosial. Ini lebih dikarenakan anggota kelompok kerja tersebut yang cenderung telah berusia tua atau diatas dari 40 tahun, sehingga jarang memanfaatkan sarana komunikasi dalam internet.

\section{J. Industri rumahan makanan ringan.}

Penduduk desa Drajat mulai banyak yang membuat hasil sampingan berupa industri rumahan makanan ringan, berupa kerupuk ikan crispy, keripik ikan, dan sebagainya. Bahan baku berupa ikan diperoleh dari hasil tangkapan ikan nelayan. Bila ikanikan tersebut diolah, dalam bentuk makanan ringan,maka harga jualnyadapat meningkat. Dan secara ekonomi akan membantu penghasilan nelayan. Bila kerupuk emping melinjo maka bahan baku emping melinjo dari luar desa, demikian pula dengan bahan baku udang. Sedangkan untuk hasil olahan berupa kerupuk ikan crispy bahan bakunya dari hasil nelayan desa Drajat.

Warga desa Drajat yang mulai meninggalkan profesi nelayan sekarang beralih menjadi produsen makanan ringan sebagai hasil olahan ikan produksi rumah tangga. Tercatat 22 jenis makanan ringan yang diproduksi,diantaranya kerupuk cumi, ikan crispy, dan berbagai jenis kripik ikan lainnya. 
Ada binaan untuk mengolah hasil keripik yaitu dari Dinas Perindustrian Kabupaten Lamongan yang diadakan di suatu hotel serta perizinan dari Dinas Perindustrian yang sudah disetujui. Semua di fasilitasi desa oleh BUMDES Desa Drajat. Produksi makanan ringan olahan dengan bahan dasar ikan yang melimpah untuk bahan baku di desa pesisir Drajat, digerakkan oleh BUMDES desa Drajat. Yaitu suatu bentuk usaha yang dikelola pemerintah desa dengan modal dan pengawasan dari pihak desa. Serta telah memperoleh izin perindustrian dari pihak Kementerian Perindustrian Kabupaten Lamongan.

\section{K. Need Assesment}

Secara ideal perkembangan TIK dapat menjadi media yang efektif dalam menyalurkan informasi dan menghubungkan interaksi melalui kecanggihan telekomunikasi. Adapun di Desa Drajat masyarakat saat ini membutuhkan pengembangan TIK seperti bisnis online dan penyerapan literasi online untuk kegiatan wirausaha. Kebutuhan ini diinginkan oleh masyarakat untuk memperluas market mereka.

Beberapa narasumber seperti Niken dan Agus menyarakan bahwa mereka tertarik untuk memasarkan produknya melalui online. Akan tetapi, selama ini masih terhambat mengenai cara untuk berstrategi dalam bisnis online, seperti posting produk dengan konten yang menarik. Selain itu, adapula dari mereka yang membutuhkan pembelajaran bisnis online dari internet. Seperti 
misalnya Nur Sodikin dan Sigit yang menginginkan adanya cara menyerap literasi bisnis online.

Untuk kalangan nelayan seperti Ropiq pada dasarnya butuh penyadaran mengenai manfaat internet. Karena Ropiq masih belum mengetahui bahwa smartphone dapat menjadi media yang menghasilkan keuntungan ekonomi. Namun berbeda dengan kalangan nelayan muda. Mereka telah mengetahui bahwa ada pemanfaatan TIK seperti internet untuk meningkatkan ekonomi dan mengentaskan kemiskinan, seperti bisnis online dan jejaring kerja via dunia maya. Akan tetapi, selama ini mereka masih bingung ingin melakukan kegiatan ekonomi apa yang sesuai dengan mereka melalui media smartphone.

Bagi Feri yang notabenya sebagai anak muda yang mahir mengenai TIK, khususnya internet dan website, dia membutuhkan satu forum yang kiranya dapat memberikan proses pertukaran pengetahuan mengenai dua hal tersebut. Dia bersedia untuk mengajari masyarakat, perangkat desa, atau rekan organisasinya mengenai internet dan website. Namun karena selama ini dia hanya tahu mengenai bisnis Forex dan jasa domain, ia masih belum banyak tahu mengenai strategi bisnis online dan jejaring usaha/kerja melalui internet.

Bagi pemerintah desa, pemanfaatan TIK, khususnya internet merupakan upaya yang harus segera dilakukan. Fauzi sebagai kepala desa, dan Tyo sebagai Direktur BUM Desa menyatakan bahwa pemanfaatan itu penting untuk mempromosikan Desa 
Drajat. Selama ini, Desa Drajat hanya terkenal mengenai wisata religinya, namun masih belum dikenal tentang keberadaan budaya dan produk-produk unggulannya. Dengan adanya usaha ekonomi kreatif masyarakat yang digerakkan oleh BUM Desa Pemaring pemerintah mengharapkan adanya gerakan promosi Desa Drajat secara online melalui internet dan media sosial. Keberadaan alunalun derajat yang berada di sebelah barat situs wisata religi dapat dipromosikan, karena di area tersebut terdapat Masjid Sunan Drajat dan aneka usaha masyarakat di pusat pertokoan BUM Desa. BUM Desa Drajat saat ini telah mengelola banyak produk unggulan desa yang diantaranya terdiri dari produksi usaha masyarakat Desa Drajat, seperti kerupuk cumi, trasi, ikan krispi, stik tepung, dsb.

\section{KESIMPULAN DAN SARAN}

Perkembangan fisik dari luar lingkungan desa telah "memaksa" masyarakat desa untuk berubah. Sebab perkembangan tadi membawa kondisi desa yang makin berubah,diantaranya cara pandang masyarakat desa Drajat terhadap arti kehidupan dewasa ini yang lebih ke arah kehidupan perkotaan (urban) area. Makna nilai ekonomi makin menguat dalam kehidupan warga desa. Fenomena ini diamati dengan makin banyaknya warung-warung di pemukiman warga desa. Kios-kios di Alun-alun Desa Drajat. Pembangunan fisik saluran air di jalan desa yang tidak dapat lagi mengandalkan tenaga gotong royong, dan musti diganti dengan 
tenaga tukang batu. Dan BUMDES (Badan Usaha Milik Desa) sebagai sokoguru/ tiang penyangga ekonomi desa telah berdiri dan dapat berjalan dengan baik.Sebab kehadiran BUMDes dapat diterima masyarakat desa Drajat seluruhnya.

Kehidupan yang makin moderen dalam arti kehidupan urban area, juga mempengaruhi warga desa untuk mencukupi penghasilan, dengan membuat aneka makanan ringan,seperti kripik dan krupuk yang hasilnya dijual. Pemasaran secara konvensional dan online.

Penetrasi Internet yang makin intensif dalam masyarakat desa, dengan penggunaan Hp, meskipu masih banyak yang hanya menggunakan Hp 2 G. Namun dengan berjalannya waktu, pergeseran pola hidup warga desa makin jelas ke arah pola kehidupan perkotaan. Dan BUMDES serta pemerintah dapat memfasilitasi membangun kembali telecenter untuk pemberdayaan ekonomi masyarakat dalam upaya mengatasi kemiskinan atau kehidupan yang makin meningkat sejahtera.Dengan demikian,telah terjadi suatu perubahan social di Desa Drajat dengan terjadinya intervensi atau masuknya internet yang dapat diakses oleh masyarakat Desa Drajat. 


\section{DAFTAR PUSTAKA}

Cangara, Hafied. 1998. Pengantar Ilmu Komunikasi. Jakarta: PT RajaGrafindo Persada.

David Simon, Leslie. 2003. Demokrasi dan Internet- Kawan atau Lawan?, Yogyakarta: Tiara Wacana.

Fiske, John.1992. Introduction to Communication studies, $2^{\text {nd }}$ Edition, New York: Routledge.

Kurnia, Novi.2019. “Pendahuluan: Urgensi Lterasi Digital Keluarga di Indonesia”, dalam Literasi Digital Keluarga,editor Novi Kurnia. Yogyakarta: Gadjah Mada University Press.

Lerner, Daniel. 1978. Memudarnya Masyarakat Tradisionil. Terjemahan Muljarto Tjokrowinoto. Yogyakarta: Gadjah Mada University Press.

Luik, Jandy. 2020. Media Baru-Sebuah Pengantar.Jakarta: Penerbit Kencana.

Maryani, Eni. 2011. Media dan Perubahan Sosial-Suara Perlawanan Melalui Radio Komunitas. Bandung: PT Remaja Rosdakarya.

Morissan,Cory,Hamid. 2010. Teori Komunikasi MassaMedia,Budaya dan Masyarakat. Bogor: PT Ghalia Indonesia.

Moleong,Lexy. 2006. Metodologi Penelitian Kualitatif. Bandung: PT Remaja Rosdakarya. 
Nasrullah, Rulli. 2018. Khalayak Media- Identitas,Ideologi,dan Perilaku pada Era Digital. Bandung: Simbiosa Rekatama Media.

Prahoro, Yuni Mogot. 2021. Manajemen Suratkabar: Panduan Ilmu,Pengetahuan,Seni,Nurani,dan Institusi. Jakarta: Penerbit Kencana.

Raco, J.R. 2010. Metode Penelitian Kualitatif-Jenis,Karakteristik dan Keunggulannya.Jakarta: Grasindo.

Suprapto, Tommy. 2019. Filsafat dan Teori Komunikasi - Sebuah Pengantar Teori,Konsep dan Filsafat Komunikasi. Yogyakarta: Pustaka Pelajar.

Wahyuni, Hermin Indah. 2020. Keriuhan Komunikasi. Jakarta: Yayasan Pustaka Obor Indonesia.

Watson, James. 1996. Media Communication, An Introduction to Theory and Process, London: Mcmillad Pres Ltd.

Wiryanto. 2000. Teori Komunikasi Massa. Jakarta: Grasindo.

Wiryanto. 2011. Komunikasi Pembangunan. Surakarta: UPT Penerbitan dan Pencetakan UNS ( UNS Press).

https://blog.ruangguru.com/7-pengertian-perubahan-sosialmenurut-para-ahli,diakses 09/7/2020 waktu 22:13 Wib 